\title{
The Nursing students' metaphors about education of anatomy
}

\author{
Tuncay Çolak ${ }^{1 a}$, B. Bamaca ${ }^{1}$, R. Tasdemir ${ }^{1}$, D. Yener ${ }^{1}$, D. Güzelordu ${ }^{1}$, İ. Sivri ${ }^{1}$, E. Aksu ${ }^{1}$, \\ and A. Özbek ${ }^{1}$ \\ ${ }^{1}$ Kocaeli University, Faculty of Medicine, Department of Anatomy, Kocaeli, Turkey
}

\begin{abstract}
Metaphor" word is described as a figurative expression in Turkish. A person transmits more explicitly his/her thoughts that are about an event or a concept he/she experienced. The aim of this study was to reveal emotions and thoughts of 1 st class students in nursing about Anatomy lesson. 62 people who are students at 1st class in Vocational School of Health Services in 2014-2015 academic year have attended to our study. In questionnaire anthropometric and demographic traits of them were asked. They were wanted to create a metaphor about anatomy by filling in the blanks in " Anatomy resembles ...../ Anatomy is like .... ; because .... " At the end of the assesment it has been detected that 44 metaphors have been produced. In these metaphors the most produced are ocean, puzzle, etc. When we divide these metaphors into categories and investigate them, there is an accumulation in discovering/revealing category with 24 metaphors. We believe that the metaphors which the students will generate, determining how to be lectured theoretical and practical anatomy lessons in a way that students are able to comprehend, will guide them.
\end{abstract}

Keywords: Metaphor; anatomy; nursing; education

\section{Introduction}

Direct Turkish equivalent of the word metaphor is "simile and analogy" [4]. We can describe metaphor as a word which is used without its real meaning by similing. A person transmits more explicitly his/her thoughts that are about an event or a concept he/she experienced. According to Kramsch [7], metaphor in traditional social psychology was a good way for expressing thoughts which weren't put into words. According to Lakoff and Johnson [7], metaphor wasn't only a verbal figure but it was also a thought figure. To be able to describe metaphor; the subject and source of it and the features of which are thought to attribute from its source to subject are neccessary [2]. In "Anatomy resembles water." ;

\footnotetext{
${ }^{a}$ Corresponding author: tuncaycolak@live.com
} 
anatomy composes the source of metaphor and water composes the subject of metaphor. It has been emphasized that the development of medicine is impossible without anatomy as the continuity of life couldn't be provided without water.

Although the metaphor researches have been commonly used in all fields of science, there haven't been too many researches in medicine. The students in Vocational School of Health Services needs knowledge of Anatomy for both the lessons they will take and performing their profession. For these students, anatomy is a difficult lesson which is needed to learn and based on Latin. They use the knowledge of Anatomy in not merely their studentships but their career as well. We think that the importance of anatomy is known in nursing. Considering this, we have aimed to reveal emotions and thoughts of $1 \mathrm{st}$ class students in nursing about Education of Anatomy.

\section{Method}

62 people(43 girls, 18 boys; 1 experimental subject has been excluded because of missing data) who are students at 1st class in Vocational School of Health Services in Kocaeli University in 2014-2015 academic year have attended to our study. In questionnaire their age, gender, the geographical region they came from, the place they were residing and why they had chosen the branch were asked. In this part their socio-economic situations were tried to learn. Besides, together with antropometric and demographic traits of them, it was tried to determine whether they had encountered Anatomy before (Table-1,2,3,4,5,6,7). Afterwards, they were wanted to create a metaphor about anatomy by filling in the blanks in " Anatomy resembles ...../ Anatomy is like .... ; because .... " The volunteer students attended to our study and only one of the surveys filled in was empty; so 61 surveys were evaluated [1]. When their personal informations are investigated, $\% 49.2$ of the students attending to study state that they chose nursing because of work guarantee after graduating. Also, it is seen that $\% 63.9$ of students who attended to our study came from Marmara Region. At the end of the assesment it has been detected that 44 metaphors have been produced. After it is calculated the number and percentage of metaphors produced, they are divided into 6 categories [1]. In these metaphors the most produced are ocean, puzzle, space, computer, map, raw meat etc. When we divide these metaphors into categories and investigate them, there is an accumulation in discovering/revealing category with 24 metaphors. However, disappearing/unknown situation category ranks in the second place with 13 metaphors. Following that, there are 10 metaphors in bitterness/pleasuere category, 9 in guidance/investing to knowledge category, 3 in desperate challenge category and 2 in finding a solution to a problem.

\section{Results}

Table 1. The students' metaphors about Anatomy

\begin{tabular}{llll}
\hline & Metaphor/Category no & Frequency & Percent (\%) \\
\hline 1 & Labyrinth(1) & 1 & 2.27 \\
2 & Enveloped(4) & 1 & 2.27 \\
3 & Football league(3) & 1 & 2.27 \\
4 & Mathematics(3) & 2 & 4.54 \\
5 & Surfing(5) & 1 & 2.27 \\
6 & Sudoku(4) & 1 & 2.27 \\
7 & Crossword(4) & 3 & 6.81 \\
8 & Ocean(1) & 4 & 9.09 \\
\hline
\end{tabular}


Table 1 (continue). The students' metaphors about Anatomy

\begin{tabular}{|c|c|c|c|}
\hline 9 & Butchery(4) & 1 & 2.27 \\
\hline 10 & Challenge(2) & 1 & 2.27 \\
\hline 11 & Complex numbers(4) & 1 & 2.27 \\
\hline 12 & Book (2) & 1 & 2.27 \\
\hline 13 & Bricks(4) & 1 & 2.27 \\
\hline 14 & Space(1) & 3 & 6.81 \\
\hline 15 & Infinity $(1)$ & 1 & 2.27 \\
\hline 16 & Systematic information(5) & 1 & 2.27 \\
\hline 17 & $\operatorname{Dolls}(4)$ & 1 & 2.27 \\
\hline 18 & Discovering(4) & 1 & 2.27 \\
\hline 19 & Raw meat(3) & 3 & 6.81 \\
\hline 20 & Literature $(6)$ & 1 & 2.27 \\
\hline 21 & An unknown $\operatorname{road}(1)$ & 1 & 2.27 \\
\hline 22 & English(6) & 1 & 2.27 \\
\hline 23 & Puzzle(4) & 2 & 4.54 \\
\hline 24 & $\operatorname{Life}(5)$ & 2 & 4.54 \\
\hline 25 & A tree at autumn $(4)$ & 1 & 2.27 \\
\hline 26 & An undiscovered continent(4) & 1 & 2.27 \\
\hline 27 & $\operatorname{Family}(5)$ & 1 & 2.27 \\
\hline 28 & Computer(4) & 3 & 6.81 \\
\hline 29 & Obligation(2) & 1 & 2.27 \\
\hline 30 & Entertainment(3) & 1 & 2.27 \\
\hline 31 & The world(5) & 1 & 2.27 \\
\hline 32 & Love(3) & 1 & 2.27 \\
\hline 33 & Water(5) & 2 & 4.54 \\
\hline 34 & Dormitory(1) & 1 & 2.27 \\
\hline 35 & Pomegranate(4) & 1 & 2.27 \\
\hline 36 & $\operatorname{Spinach}(3)$ & 1 & 2.27 \\
\hline 37 & Chocolate (3) & 1 & 2.27 \\
\hline 38 & $\operatorname{Map}(4)$ & 3 & 6.81 \\
\hline 39 & Parents(5) & 1 & 2.27 \\
\hline 40 & Dictionary(4) & 1 & 2.27 \\
\hline 41 & Windows(4) & 1 & 2.27 \\
\hline 42 & Mountain(4) & 1 & 2.27 \\
\hline 43 & Mysterius garden(4) & 1 & 2.27 \\
\hline 44 & Nature (3) & 1 & 2.27 \\
\hline
\end{tabular}

Ocean $(\% 9.09)$,computer $(\% 6.81)$,raw meat $(\% 6.81)$, crossword $(\% 6.81)$, space $(\% 6.81)$ and map $(\% 6.81)$ are the students' metaphors about anatomy which are more than the others.

Table 2. The distribution of students according to the region they came from

\begin{tabular}{ll}
\hline The region he/she came from & Numbers (percent) \\
\hline Marmara & $39(\% 63.9)$ \\
Aegean & $3(\% 4.83)$ \\
Mediterranean & $5(\% 8.06)$ \\
Central Anatolia & $4(\% 6.45)$ \\
Black Sea & $6(\% 9.67)$ \\
Eastern Anatolia & $3(\% 4.83)$ \\
South Eastern Anatolia & $2(\% 3.22)$ \\
\hline
\end{tabular}

The students generally came from Marmara Region (\%63.9) to the school. 
Table 3. The distribution of the students' gender

\begin{tabular}{lll}
\hline Gender & Frequency & Percent \\
\hline Female & 42 & 68.85 \\
Male & 18 & 29.50 \\
\hline
\end{tabular}

The students are mostly girls $(\% 68.85)$.

Table 4. The places where the students have been residing

\begin{tabular}{lll}
\hline Inhabitancy & Frequency & Percent \\
\hline Dormitory & 36 & 59.01 \\
House & 25 & 40.98 \\
\hline
\end{tabular}

The students commonly stay in dormitory by 59.01 percent.

Table 5. The reasons why students prefer the department

\begin{tabular}{lll}
\hline $\begin{array}{l}\text { The reason of preferrence of } \\
\text { department }\end{array}$ & Frequency & Percent \\
\hline The request of family & 7 & 11.47 \\
My own request & 24 & 39.34 \\
Business guarantee & 30 & 49.18 \\
\hline
\end{tabular}

Almost half of the students $(\% 49.18)$ prefer nursing because of business guarantee.

Table 6. Categories of obtained metaphors

\begin{tabular}{llll}
\hline Category & Female & Male & Total \\
\hline 1.Disappearing/Unknown situation & 10 & 3 & 13 \\
2.Desperate challenge & 1 & 2 & 3 \\
3.Bitterness/Pleasure & 6 & 4 & 10 \\
4.Discovering,revealing & 18 & 5 & 23 \\
5.Guidance, investment to the & 5 & 4 & 9 \\
knowledge & 2 & - & 2 \\
$\begin{array}{l}\text { 6.Finding a solution to a problem } \\
\text { 7.Bitter }\end{array}$ & - & - & - \\
$\begin{array}{l}\text { 8.The emotion of having been } \\
\text { flown/unhealthy pleasure }\end{array}$ & - & - & \\
& 42 & 18 & 60 \\
\hline
\end{tabular}

The students' metaphors are mostly in discovering,revealing (23 of 60 students) category.

Table 7. Distribution by geographical areas category

\begin{tabular}{llllllll}
\hline $\begin{array}{l}\text { Category } \\
\text { No }\end{array}$ & Mediterranean & $\begin{array}{l}\text { Black } \\
\text { Sea }\end{array}$ & $\begin{array}{l}\text { East } \\
\text { Anatolia }\end{array}$ & $\begin{array}{l}\text { Central } \\
\text { Anatolia }\end{array}$ & $\begin{array}{l}\text { South East } \\
\text { Anatolia }\end{array}$ & Aegea & Marmara \\
\hline 1 & 1 & 1 & & & 1 & 1 & 8 \\
2 & 1 & & & & & 2 \\
3 & & 1 & & & & 2 & 7 \\
4 & 2 & 2 & 3 & 2 & 1 & 1 & 15 \\
5 & 1 & 1 & & 2 & & & 5 \\
6 & & & & & & & \\
7 & & & & & & & \\
8 & & & & & & & \\
\hline
\end{tabular}

The metaphors of the students who came from Marmara. East Anatolia. Black Sea and Mediterranean mostly in category 4 (discovering,revealing). 


\section{Discussion and conclusion}

The metaphor can be used for pedagojical purposes successfully [3]. We have ascertained in the literature we performed that metaphors are used in the fields of education and training $[4,5,6,9,10$ and 11]. Starting from this point of view, we have been searching for the answer to the question of "What are the metaphors of nursing students about Anatomy training and education" [4]. As mentioned above, it is seen that the students have chosen mostly discovering/revealing metaphors as a metaphor category. This is why students first anatomically investigate the human body so closely, in a theorical and practical manner. In theoric and practic Anatomy lessons, new Latin description for each new organ provided comprising the emotion of discovering. We believe that the metaphors which the nursing students will generate, to be able to be a successful person in health field and have a strong anatomical basis in determining how to be lectured theorical and practical lessons in a way that students are able to comprehend, will guide them. The fear, anxiety, curiousity and requests of students about Anatomy will have been stated in a metaphoric way. Thereby, in lecturing the lessons, these emotions will be considered and more impressive approach will be able to be shown.

\section{References}

1. Aktekin, M. \& Aktekin, N. C. Anatomi öğrenmenin kaçınılmaz acısı. Paper presented at the XIIIth National Congress of Anatomy with International participation, Kyrenia, Turkish Republic of Northern Cyprus, 28th October-1st November, 2., (2010).

2. Aybek, H., Akdoğan, I., Tok, Ş. \& Tok, T. N. Metaphors Put Forward By Medical Faculty Grade I, II And III Students Of PAU. Tıp Eğitimi Dünyası Dergisi. 18(2), 273312., (2012).

3. Boers, F. Metaphor awareness and vocabulary retention. Applied Linguistics, 21, 553571., (2000).

4. Colak, S. Metaphoric Perceptions of School of Physical Education and Sport Students to the Concept "Computers Education". Procedia-Social and Behavioral Science, 174, 3210-3213., (2015).

5. Guerrero, M. C. M. \& Villamil, O. S. Metaphorical conceptualizations of ELS teaching and learning. Language Teaching Research. 6(2), 95-120., (2002).

6. Kalyoncu, R. Visual arts teacher candidates metaphors related to concept of teaching. Mustafa Kemal University Journal of Social Sciences Institute, 9(20), 474-484., (2012).

7. Kramsch, C. Metaphor and the subjective construction of beliefs. In: Kalaja, P. and Barcelos, A.M.F. (eds.). Beliefs about SLA: New research approaches. Springer, pp.109-128., (2003).

8. Lakoff, G. \& Johnson, M. Metaforlar Hayat Anlam ve Dil (Translation: Gökhan Yavuz Demir). İstanbul: Paradigma Yayıncilik., (2005).

9. Ozturk, C. Sosyal bilgiler, sınıf ve fen bilgisi öğretmen adaylarının coğrafya kavramına yönelik metafor durumları. Kırşehir Eğitim Fakültesi Dergisi. 8(2), 55-69., (2007).

10. Saban, A. Giriş düzeyindeki sınıf öğretmeni adaylarının öğretmen kavramına İlişkin İleri Sürdükleri metaforlar. Türk Eğitim Bilimleri Dergisi. 2(2), 131-155., (2004).

11. Saban, A. İlköğretim I. kademe öğretmen ve öğrencilerinin bilgi kavramına ilişkin sahip oldukları zihinsel imgeler. İlköğretim Online.7(2), 421-455., (2008).

12. Saban, A., Kocbeker, B. N. \& Saban, A. Öğretmen adaylarının öğretmen kavramına ilişkin algılarının metafor analizi yoluyla incelenmesi..Kuram ve Uygulamada Eğitim Bilimleri, 6(2), 461-522., (2006). 